Sign Systems Studies 36.1, 2008

\title{
Vico and Lotman: poetic meaning creation and primary modelling
}

\author{
Tuuli Raudla \\ Department of Semiotics, University of Tartu \\ Tiigi 78, 50410 Tartu, Estonia \\ e-mail: tuuli_raudla@hotmail.com
}

\begin{abstract}
The article is based on theories of meaning creation and the concepts of archaic mind of Juri Lotman and Giambattista Vico. It compares the notions fantasia, ingegno, memoria and poetic logic by Vico with Lotman's concepts of text, memory and modelling systems. Donald Phillip Verene's and Marcel Danesi's interpretations of Giambattista Vico's work are also taken into consideration in the analysis. The article aims to bring out the characteristic features of archaic meaning creation. The archaic mind is considered to be fundamentally poetic. Its main mechanism of generating new meaning is metaphorical identification of two otherwise separate elements. The creativity of this act lies in the presumption that imagination is needed to bring these two elements together - they cannot be identified with each other by the means of syllogistic logic. The archaic mind does not operate mainly with generic concepts, as rational mind does. It forms imaginative universals instead, which are based on the sense of identity between objects or their parts, not on the sense of similarity/ dissimilarity of distinct features of objects. This process forms the basis of poetic modelling, which is primary in relation to verbal modelling.
\end{abstract}

We find not Occam's razor, but Vico's magnet. Donald Phillip Verene

\section{Introduction}

The aim of this article is to bring out some specific features of the archaic mind based on the works of two rather different authors: the 


\section{Tuuli Raudla}

18th century Napolitanian philosopher Giambattista Vico and Juri Lotman, a semiotician of the Tartu-Moscow school. The works of Giambattista Vico and Juri Lotman have previously been compared only once - by Marcel Danesi (2000) in his article $A$ note on Vico and Lotman.

According to Giambattista Vico, the archaic people organized their world in a principally different way from the bearers of modern mind. Vico's main premise is that the archaic mind is poetic. He maintains that the poetic principle also has an important role in the modern mind, especially in the process of meaning creation. Juri Lotman and Boris Uspenskij (1978b) also proposed a form of thought that operates differently from descriptive thought in their article Myth - Name Culture.

There are many views on the concept of archaic mind. Lucien Lévy-Bruhl with his notion of "savage mind" is usually considered to be the first who saw the archaic thought to be essentially different from the modern (Harkin 1998: 365). The best known treatment of the matter is Claude Lévi-Strauss's The Savage Mind (1969 [1962]). The present article takes it that the notion of poetic thought sets Giambattista Vico to be the first who saw the so-called primitive mind as typologically different. More than two hundred years before LéviStrauss, Vico described a mind that operates on the basis of poetic logic instead of syllogistic logic. According to Vico, the archaic mind is essentially poetic and metaphorical, it has the capacity to generate language due to a primordial imagination. In Vico's system, human thought began with, as Danesi (1993: 52) puts it "[...] primordial mind that would have had the capacity to generate language. The essential feature of this mind is imagination. It was therefore a mind that did its work on the basis of bodily experience, not analysis and deduction".

Vico's treatment of the matter bears much resemblance to Lotman's notion of mythological thought as a type of consciousness. Both authors base their analysis on the proposition that by analysing the structure of culture, it is possible to define the structure of consciousness. Vico sees imagination as the nexus of the beginning of human semiosis, Lotman (2005: 162) claims that "at first there was semiotic experiment".

The concepts of primordial knowledge and meaning creation of Vico and Lotman will be viewed here as partly coinciding and complementary. We treat the primordial poetic mind as an indepen- 
dent and specific type of consciousness, but do not presuppose its actual occurrence in "pure" form.

Outlining his concept of the archaic mind, Vico claims that we cannot access the primordial thought directly. "It is beyond our power to enter into the vast imagination of those first men" (Vico 1984: 378). Trying to make sense of it, "we had to descend from these human and refined natures of ours to those quite wild and savage natures, which we cannot at all imagine and can comprehend only with great effort" (Vico 1984: 338).

The incapability to imagine the archaic world means that the modern mind is not able to model it completely - although it is possible to recognize the existence of a basically different type of consciousness and acquire adequate knowledge of it to some extent.

The Tartu-Moscow school's view on mythology is compatible with this approach.

Consistently mythological stage should pertain to a period of development that is so early that it cannot be observed both for chronological reasons and because of the basic impossibility of coming in contact with it [...] mythological consciousness in principle cannot be translated into the level of a different description, is in itself closed. (Lotman, Uspenskij 1978b: 218219)

Linking mythological thought with primordial knowledge, the primal form of semiotic thought, and approaching the workings of the mind through the analysis of the semiotic world it creates, The New Science of Vico has inspired several interpretations by semioticians in the past two decades (Danesi 1991, 1995a, 1995b, 2000; Sebeok 2001; Verene 1991, 1995). The semiotic interpretation of Vico is relatively coherent, probably partly because only two authors - Donald Phillip Verene and Marcel Danesi — have so far aimed to apply Vico's concepts directly to semiotic theory.

Vico's approach to the notion of metaphor contains views that have been considered innovative even in the last two decades. Frank Nuessel (1995) notes in his essay Vico and Current Work in Cognitive Linguistics that, for example, George Lakoff's view on metaphor, language and imagination is Vichian in its nature, although having had no direct influence from Vico. 


\section{The elements of poetic meaning creation}

In Vico's mind, the beginning of human world is linked to the appearance of language. Vico describes the genesis of linguistic capacity, not of speech. Language appears as poetic characters (caratteri poetici) (Vico 1984: 34), which are not verbal. According to Vico, the primal language was mute (Vico 1984: 401, 434; also Ponzio 2006: 238). Although Vico considers verbal speech to be neither the first nor the only expression of the capability of language, he approaches the question with a philological-philosophical method - by trying to discover the primordial iconic nature of words in etymology. Verbal expression, although not uniquely, mirrors the modifications of the mind. Vico's apprehension of consciousness and culture has a common base with Lotman - they both believe that the structure of consciousness can be described through the structure of culture, and use the analysis of texts to draw conclusions about the human mind. Obviously, the materials Vico uses when modelling the archaic consciousness are products of a more contemporary mind - the epics of Homer, for example, are texts that mirror the archaic mind, although they were born in the process of translating myth into poetry. The only way to understand the archaic mind is through such kind of translation.

Lotman and Uspenskij propose that from the standpoint of mythological consciousness, poetry is impossible (1978b).

On the other hand, Lotman concedes that "the functional confrontation of art and myth is born on the account of the possibility to 'read' mythological texts in a non-mythological way" (Lotman, Mints 1981c: 46). For Vico, myth is poetic and at the same time it is primordial. In The New Science, 'poetic' signifies certain firstness, a category prior to logical abstraction. "In Vico's view the poetic, or what in more modern terms we would call the myth, is the beginning of knowledge" (Verene 1995: 203).

Lotman's cultural-typological discrimination that excludes poetry from mythological world is grounded on defining poetry as free art of words. But Vico sees the poetic creation as a kind of true narration, rather than as free art of words (Vico 1984: 401) — as myth in modern terms.

Thus, in describing primordial meaning creation, Vichian tradition has used the term 'poetic', whereas the Tartu-Moscow school uses the 
term 'mythological'. Both approaches discriminate between the modern and archaic culture by distinct features of the meaning creation mechanism. In the current treatment, the term 'poetic' will be favoured. Both terms have many meanings that have little to do with this discussion, but 'poetic' is - for its connection to metaphor theory - more apt for the sense intended here.

\subsection{Lotman's notions 'memory' and 'text' in connection with Vico's 'fantasia', 'ingegno', 'memoria'}

Vico's view on meaning creation can be presented through the notions of fantasia, ingegno, and memoria. For Vico, these terms signify primordial capabilities that allow for the primary operations of the human mind. (Vico 1984: 494-497). In Vico's mind, all primary cognitive functions are attached to imagination. The three terms describe three main functions of the primordial mind: fantasia - the ability to imitate and change; ingegno — the ability to create correspondence between things; memoria - the ability to remember (Vico 1984: 819).

Fantasia, ingegno and memoria integrate through identification, all of them being forms of imagination.

Imagination however, is nothing but the springing up again of reminiscences, and ingenuity or invention is nothing but the working over of what is remembered. [...] since the human mind at the time we are considering [...] had not developed its powers of abstraction by the many abstract terms in which languages now abound, it exercised all its force in these three excellent faculties which come to it from the body. (Vico 1984: 699)

\subsubsection{Textuality}

Individual human mind can be seen as a text. It is at least bilingual semiotic monad (Lotman 1997: 10). No text can exist in isolation. A text functions only in reciprocal relations with external elements, which means that the text is continuously in the situation of translation. "The very existence of culture implies the construction of a system, of some rules for translating direct experience into text" 


\section{Tuuli Raudla}

(Lotman, Uspenskij 1978a: 214). In Vico's treatment of the primordial mind, this system is formed in the activity of fantasia and ingegno.

Fantasia as the ability to imitate is interpreted by Marcel Danesi as the capability to form mental images. "The fantasia's image-making capacity is a primordial power of the human mind that makes cognition itself possible" (Danesi 2000: 103). The creativity of fantasia lies in its ability to separate an object from its direct context, so that it can be included in the process of thought as an arbitrary image and can as such serve as the basis for creating new mental entities by entering freely into new connections (Danesi 2000: 102). Fantasia, ingengo and memoria are the powers necessary for creating and preserving mental images - they are the foundation of human meaning creation and free combining. This view on the peculiarity of anthroposemiosis is in accordance with John Deely's conception, where uniquely human capability of creating textuality is characterised by

signs whose relation to what they signify, over and above associations among perceptible objects, is grounded in the codes of an apprehension socialized through free play among objects understood in their detachability from the perceptible means whereby they are brought into experience in the first place or any given case. (Deely 1991: 545)

Fantasia's nature and function, as described by Danesi, are also compatible with Lotman's view on the premises of the appearance of semiotic world:

The transformation of the world of objects into the world of signs is founded on the ontological presupposition that it is possible to make replicas: the reflected image of a thing is cut off from its natural practical associations (space, context, intension, and so on), and can therefore be easily included in the modelling associations of the human consciousness. (Lotman 2001: 54)

Human being is able to make replicas owing to fantasia - he/she imitates, creates mental images based on perceptional information; uses ingegno to relate images to each other; and is able to preserve the images by memoria. According to Danesi, ingegno is the power that allows for the appearance of entirely new entities within the mental space (also Verene 1991: 105): 
the ingegno is a derivative of fantasia - a kind of "epiphenomenal" activity, stimulating the mind to carry out its creative handiwork. It is thus not connected directly to neural processes, operating totally within mental space as it configures and creates models of world events. (Danesi 2000: 104)

Similarly to the model based on the terms 'fantasia', 'ingegno' and 'memoria', Lotman describes text as an intellect-like mechanism, the main characteristics of which are that: "it has memory, where it can concentrate its previous meanings, and, at the same time, it has the ability to produce new nontrivial messages when connected to a communicative chain" (Lotman 1981a: 7). Ingegno produces imaginative structures - new units of meaning — presupposing the existence of perceptually obtained images (fantasia) and the capacity to save them (memoria).

Text functions as a meaning creating mechanism if the process of associating the so far incompatible, translation in the situation of untranslatability, takes place (ingegno's function in Vichian system). "The asymmetrical relationship, the constant need for choice, make translation in this case an act of generating new information and exemplify the creative function both of language and of the text" (Lotman 2001: 14-15).

The archaic human mind was not a passive system that suddenly obtained the capability of language and rational thought - these faculties appeared as an extension of bodily experience. For Vico, imagination is a primordial innate power that is strongly attached to body and senses. "It is true that these faculties (fantasia, ingegno, memoria) appertain to the mind, but they have their roots in the body and draw their strength from it" (Vico 1984: 819). Primary textuality that enables to recognize a stimulus as semiotic, originates from the body. So for Vico meaning creation departs from body and individual consciousness. For Lotman individual consciousness is central: "the intersection of meaning-spaces, which gives birth to new meaning is connected to individual consciousness" (1992: 36).

\subsubsection{Memory}

It is clear that for Lotman, one of the necessary properties of text/ intellect is memory (Lotman 1981a: 7; 1995: 9; 2001: 18 and elsewhere). Memory also has a special place in Vico's system. He 


\section{Tuuli Raudla}

understands memory not as some passive storage space, but as an imaginative faculty. Nevertheless, Vico does not analyse memory explicitly in The New Science; he only mentions that memory is the mother of muses (Vico 1984: 699; 819). Another point of departure analysing the Vichian notion of memory is its identifiability with imagination. Vico calls fantasia, ingegno and memoria the three aspects of memory (Vico 1984: 819). In Vico's system, which allows identity between the elements, such a statement is not in the least paradoxical. In a certain sense, fantasia, ingegno and memoria are one and the same and they can be seen as three aspects of the same phenomenon. Still, it is necessary to discriminate between memoria and memory that embraces all the three above-mentioned terms. Memoria is more specific and signifies "memory when it remembers things" (Vico 1984: 819). To avoid mix-up between the two forms of memory, Verene proposes the notion "recollective fantasia".

Each term of Vico's "three memories" - memoria, fantasia, and ingegno is inseparable from others. They are a totality. [...] I wish to use "recollection" for this composite sense of memory [...], more precisely — recollective fantasia. (Verene 1991: 101)

Recollective fantasia is a form of imagination that makes it possible to reflect over images. It comprises memoria, primal imagination (fantasia) and invention (ingegno), but it is not just a sum of them it is formed by imaginative universals created by the three faculties. It is the level of primal reflection - reflection by images, not by concepts. It can be considered the primordial cultural memory that is structured imagistically, that is by imaginative universals (Verene 1991: 99).

Memory gives us the opportunity of going back and reflecting over the initial state, the point of departure. If we are dealing with a new unit of meaning, the moment of its appearance can never be defined conclusively - memory constructs it over and over again with each attempt of return, at the same time never really losing contact with the primal sensational stimulus.

In Vico's view memory [...] has the power to take the knower back toward the level of sensation, to place the mind back in touch with the original powers of sensation. Memory is corrective of the mind in its thrust toward conceptual abstraction. (Verene 1991: 103) 
Memory thereby ensures, re-controls the operation of the mind. Undoubtedly, this leads to creating new links between elements, while the primal imaginative structure may persist besides the new one. This situation can be characterized as one, where consciousness is semiotic "food" for itself (Lotman 1997: 10). Lotman also describes the function of memory as the ability to turn back:

Memory connects into the mechanism, allowing us to return again to the moment preceding the explosion and go through the whole process once more, but already in retrospect. Now it is as if there are three layers in the consciousness: the moment of the original explosion, the moment of editing it in the mechanisms of conciousness, and the moment of its new duplication in the structure of memory. (Lotman 1992: 232)

The corrective function of memory appears in Lotman's conception as well. The moment of new duplication may be understood as the moment when saved images enter into new connections and the above-mentioned process of self-transformation of the semiotic monad is initiated. Although Verene claims that memory in Vico's view allows us to return to the level of sensation, it is clear that the process is retrospective - memory is turning back to the sensory sign. Memory in Vico's sense has the peculiarity of being preconceptual and imagistically structured — so the relatively direct connection between the image and the percept makes access to the primal situation, the moment of saving the images, more immediate. Lotman and Uspenskij describe the process of saving an element in memory as follows: firstly, the object must be recognized as existing; then it has to be identified with a certain element in languages in order to be connected to memory. Next, the element is evaluated according to the hierarchical relations of language. When set into the hierarchy of language, the image turns into an element of memory as text (Lotman and Uspenskij 1978a: 214).

\subsection{Metaphorical identification as the base for creating imaginative universals}

In The New Science, Vico describes imaginative universals (universali fantastici, generi fantastici) that differ principally from the generic concepts used in conceptual thinking. 


\section{Tuuli Raudla}

the first men [...] not being able to form intelligible class concepts of things, had a natural need to create poetic characters; that is, imaginative class concepts or universals, to which, as to certain models or ideal portraits, to reduce all the particular species which resembled them. (Vico 1984: 209)

Vico discriminates between generi intelligibili and generi fantastici typologically. Poetic thought is organized in a specific way and it is not merely a simplified form of conceptual thought — poetic thought is an independent form of organizing the world. The notion of imaginative universals is difficult to interpret in standard philosophical terms, because it is a theory of image rather that a theory of concept in traditional sense (Verene 1991: 68).

The generic concepts of traditional Aristotelian logic are formed by the mind's power to select from a multiplicity of particular things those features that are common to all. Objects are collected into classes in terms of their possession of some common property. (Verene 1991: 72)

The basis of imaginative universals is metaphorical identification, which is not based on dividing the objects into properties. The role of tropes in language has been of interest for many scholars in the last decades and the number of publications on metaphor is enormous, as Danesi (1993: 122) indicated already more than ten years ago. But the assertion that archaic consciousness structured itself primarily metaphorically is not at all trivial. Direct parallels to this argument of Vico's may be found not sooner than in the metaphor theory of George Lakoff and Mark Johnson, who assert that it is hard to find a general subjective experience, which would not be conceptualized metaphorically (Lakoff, Johnson 1999: 45). In addition, Lakoff and Johnson describe, similarly to Vico, primary conceptualization as an outgrowth of bodily experience (Lakoff, Johnson 1999: 6).

Imaginative universal is a particular kind of metaphor. Vico does not understand metaphor in its usual sense, but as an image-creating process, that conveys identity not similarity (Haskell 2000: 354; Verene 1995: 206). "Every metaphor [...] is a fable in brief", writes Vico (1984: 404). At the basis of metaphor is

the principle of the true poetic allegories which gave the fables univocal not analogical meanings for various particulars comprised under their poetic genera. They were therefore called diversiloquia; that is, expressions 
comprising in one general concept various species of men, deeds, or things (Vico 1984: 210).

So we are dealing here with a process, where there is no analogy in its ordinary similarity based sense and the particular is connected to the general not by common features, but by identity. This peculiar feature of imaginative universals - being based on "a primordial sensory identity" (Haskell 2000: 354) — is the key to their primacy. "The verb 'to be', 'is' always points at once in two directions - to the being or existence of the thing and to its sense as copula, as the relation of two orders" (Verene 1995: 206). When the archaic people created the first imaginative universal, two things emerged - the ability to sense something as existing (a mental image brought to consciousness by fantasia) and its relation to something else.

"When men are ignorant of the natural causes producing things, and cannot even explain them by analogy with similar things, they attribute their own nature to them" (Vico 1984: 180). Thus interpreting the world started with attributing bodily nature to the surrounding environment - foremost to the sky, which came to be the first imaginative universal Jove. "Jove as an imaginative universal is the first expression of 'isness'. Something now is where before only momentaryness reigned. Jove both is in the sense of being something and $i s$ in the sense of being related to something" (Verene 1995: 206). All through The New Science Vico speaks of Jove as the first imaginative universal. He assumes that Jove appeared induced by fear: "It was fear which created gods in the world; not fear awakened in men by other men, but fear awakened in men by themselves" (Vico 1984: 382). In Vico's view the stimulus for the first identification was an individual bodily experience - fear of thunder. This had to be strong enough, so that the momentary perception of thunder would be connected persistently to the emotion and the experience would be preserved outside its context in consciousness as an image (Haskell 2000: 353). The first universal is a starting point for the formation of social institutions.

Jove is a kind of sensory topos (topica sensibile) from which they can draw forth all the further meanings their surroundings and create the sensus communis or il senso comune, the "communal sense" that is the basis of human mentality and society. (Verene 1995: 206) 


\section{Tuuli Raudla}

For Vico the first god is created in fear and at the same point rises $i l$ senso commune. Lotman describes the appearance of the phenomenon of thought as well as a moment of extreme incertitude that conditions the need for religion and culture.

On the one hand, it would be natural to compensate the increase of uncertainty and lack of knowledge with turning to protective beings, who are omniscient. The emergence of religion, coinciding with the stadium of the genesis of thought, is, without a doubt, not a coincidence. [...] The second means for overcoming the emerging difficulties was appealing to a collective mind, that is, to culture. (Lotman 1978: 16)

In the article Myth - Name - Culture, Lotman and Uspenskij (1978b: 219) understand metaphor as an entity that belongs to the sphere of descriptive thought and that is impossible in the mythological consciousness. They define metaphor differently from Vico: as tied to similarity — to a mechanism that also in Vico's view does not belong to primordial poetic consciousness. Vico's understanding of the metaphor finds a parallel in the notion of mythological identification - isomorphism. "Mythological identification is in principle of an extratextual nature, arising on the basis of the inseparability of the name from the thing" (Lotman, Uspenskij 1978b: 224). As a result "mythological identification presupposes the transformation of the object, which occurs in concrete space and time" (Lotman, Uspenskij 1978b: 226). In mythological thought, the copula does not mark a relation based on descriptive logic, but direct identification (Lotman, Uspenskij 1978b: 212). So the two orders that are connected do not relate to each other as object-level and metalevel, but can replace each other in the consciousness by means of transformations.

Describing mythological consciousness, Lotman notes that: "This powerful identification that lies in the base of this type of consciousness forces to see signs of One phenomenon in the different phenomena of the real world and view a Single Object in the diversity of objects belonging to one class" (Lotman 1978: 6). What seems to be a set of similar objects to the bearer of modern consciousness, is an expression of one object for the bearer of archaic mind.

Lotman and Uspenskij (1978b: 221) describe mythological cognition as such, "where signs are not attributed, but recognized and the act of nomination itself is identified with the act of cognition". Thus the first time cognition is at once the first time nomination - and the 
whole process is apprehended as recognition - at this level of consciousness there is no discrimination between the sign and the object, they appear simultaneously in the consciousness.

Vico phrases the thought process of the archaic mind as follows: "By their logic they had to put subjects together in order to put their forms together, or to destroy a subject in order to separate its primary form from the contrary form which had been imposed upon it" (Vico 1984: 410). The archaic mind operated with units that were not dividable into distinct features; bringing the meaning units of poetic logic to the elementary level, we do not get a list of features, but a part of the unit that is a whole in itself. Imaginative meaning units were formed by combining the parts or understanding the primal image as a universal: "particulars were elevated into universals or parts united with the other parts together with which they make up their wholes" (Vico 1984: 407).

Coming back to the faculties of the archaic consciousness: metaphorical identification is made possible by the workings of fantasia and ingegno.

For Vico metaphor is a mental capacity that results from the interaction of the fantasia and the ingegno. As these two deep-level faculties perform their function in tandem, they generate metaphor, which can be defined as a kind of epiphenomenal amalgam of fantasia and ingegno. (Danesi 1995b: 72)

In Danesi's interpretation the cooperation of fantasia and ingegno takes place wholly in the mental space. Perceptual images are restructured and the entities that result in this process have no direct relation to perception (Danesi 1995b: 72). Although it is clear that the human mind allows for noncontextual free combining and genesis of new units of meaning purely within the mental space, fantasia understood as a bodily imagination can be seen as a bridge between body and consciousness. 


\title{
2. Poetic logic as the deep structure of a primary modelling system
}

\subsection{The theory of modelling systems}

'Modelling systems' is originally a term of the Tartu-Moscow school. Modelling systems were described as primary or secondary. In the original conception natural language was the primary modelling system. Secondary modelling systems were superlinguistic systems with two or more layers, which were translatable into natural language (Ivanov et al. 1998: 80-81; Lotman 1967: 131). In his theses Art Among Modelling Systems, Lotman (1967) describes modelling activity and modelling systems in the following way:

\begin{abstract}
Modelling activity is human's activity in creating models. In order for the results of this activity to be received as the analogies of an object, they have to comply with certain (intuitively or consciously defined) rules of analogy and, consequently, correlate to one or another modelling system.

Modelling system is a structure of elements and rules of their combination, existing in a state of fixed analogy in relation to the whole domain of the object of cognition, recognition or organisation. For this reason, a modelling system may be regarded as a language. (Lotman 1967: 130-131)
\end{abstract}

The two main characteristics of modelling systems can be found here. Firstly, it expresses itself as a structure based on a number of elements and a set of rules for linking them. Secondly, a modelling system has a fixed relation to its object, which is expressed in certain rules of analogy.

Apparently, Lotman understands language here in a more general way - not in the narrow sense of verbal semiosis. In some cases, Lotman uses 'language' in the sense of an organization of whatsoever kind. For example, he defines trope as a phenomenon appearing at the point of contact of two languages (Lotman 2001: 44) and describes the usage of tropes in zoosemiotic communication, where the two 'languages' in contact are in fact animal communication systems (Lotman 2001: 38). Thus, it would be unadvisable to conclude that in Lotman's view all modelling systems, that is, languages, are related to verbal code.

The relation between a modelling system and an object is tied to the nature of the model: 
A model differs from a sign as such in that it does not simply substitute a denotatum, but substitutes it in a useful manner in the process of cognising or organising the object. This is why if the relation of language to the denotatum in a natural language is historical-conventional, then the relation of the model to the object is determined by the structure of the modelling system. In this sense, only one kind of signs - ic onic signs - may be equated to models. (Lotman 1967: 131)

Therefore, models are created in the process of cognizing and organizing the object. The model and the object are not connected conventionally but iconically. Information that the iconical sign carries is inseparable from the modelling language and the structure of the model (Lotman 1967: 131).

Lotman has been criticized for his concept of the natural language as a primary modelling system, mainly by Thomas A. Sebeok. In fact, Lotman did not rule out the possibility that nonverbal systems could function as primary ones.

Primary coding, according to Lotman (1990: 58 [here 2001: 58]), is not restricted to verbal language. Much of the reality of human life evinces primary coding, which begins with the perceptual act of filtering cognitively significant from nonsignificant elements, a process which takes place at each level of coding, but separates the semiotic from the nonsemiotic world at the lowest level of semiosis. (Nöth 2006: 257-258)

In his article "In what sense is language a "primary modelling system'?", Sebeok (1988) interprets Lotman differently. He bases his modelling system theory on the discrimination between verbal and non-verbal communication systems. At the same time, he mentions that it is very likely that the Homo habilis had the capability of language without any verbal expression (Sebeok 1988: 75; also Danesi 2000b: 127). Thus, the differentiation between verbal and nonverbal does not coincide with the distinction between linguistic and nonlinguistic. In the current discussion, the emphasis is on the last one, because it is more directly related to the subject of mental processes involved in creating universals. Therefore, Sebeok's conception of nonverbal modelling as the primary one does not fit in this treatment.

The Forms of Meaning by Sebeok and Danesi (2000) has remained the only thorough treatment of the subject of modelling systems. The authors base their analysis on the thesis that modelling is proper to all 


\section{Tuuli Raudla}

life forms: modelling is a derivate of semiosis (Sebeok, Danesi 2000: 5). Sebeok and Danesi divide the modelling systems into three groups according to the Percian three types of sign relations: firstness, secondness, thirdness - primary modelling systems are iconical, secondary indexical, and tertiary symbolical (Sebeok, Danesi 2000: 10). Thus the differentiation is based on the types of signs, even though the peculiarity of anthroposemiosis is not determined by the types of signs we use, but how we create and organize them (Ponzio 2006: 240). Sebeok and Danesi (2000: 52, 95, 121) themselves note that other animals use symbols just as well as icons and indexes. Thus in their discussion they are forced to use the terms 'artificial' and 'verbal' (Sebeok, Danesi 2000: 60) to indicate phenomena belonging exclusively to human semiosis, and the term 'natural' (Sebeok, Danesi 2000: 60, 95) to indicate modelling systems proper to all species. Such differentiation does not allow for the specification of how human modelling systems are different from zoosemiotic modelling systems. Putting the emphasis on verbality leads to phonocentrism; the contradistinction artificial-natural is quite useless if not theoretically specified.

\subsection{Poetic modelling}

Modelling systems that are proper to all life forms are a part of anthroposemiosis. "More fundamentally and inclusively, anthroposemiosis comprises all of the sign processes that human beings are directly involved in" (Deely 2005: 33). Human beings are influenced by all sorts of sign processes - from the cellular level to interpersonal verbal communication. Although there is no reason to doubt that the human biological being and the capability of language are intertwined, it may not be useful to consider language as secondary or tertiary among the bio- and zoosemiotic systems. In the original differentiation of primary and secondary modelling systems, there was no ambition of universality. In his article Yuri Lotman on Metaphors and Culture as Self-Referential Semiospheres, Winfried Nöth (2006) notes that the terms were relational:

[...] primary vs. secondary is never a categorical but always a relational opposition. What is primary at a higher level may be secondary from the 
perspective of a lower level and even twice secondary from the point of view of a still lower level. (Nöth 2006: 259)

Not trying to determine the absolutely primary modelling system, Lotman defined cultural phenomena as secondary modelling systems for the reason that they need to be translated into natural language at some stage (Lotman 1967: 131). In the context of this discussion, it is not useful to transfer the relational opposition to an absolute scale. In addition, it is impossible to deny the particular role of linguistic thought in the human conception of the world. "However, insofar as that sensory system or any other biological system is articulated and described in language, its priority and transparency would be compromised and undermined" (Chang 2003: 11).

Therefore, we can speak of the primary level of language and the primordial poetic mechanisms of meaning creation as primary modelling - as far as we are dealing with specifically human modelling systems and bear in mind their relation to biosemiotic processes. Similarly, Augusto Ponzio argues in his article Metaphor and Poetic Logic in Vico that language is a modelling capacity specific to humans, which has its roots in the body and is to be considered primary (Ponzio 2006: 238-239). The first scholar to note the parallel discussed here between Lotman's notion of modelling and Vico's concept of meaning creation was Marcel Danesi, who marked: "Essentially, as I read Lotman with 'Vichian eyes', I see his notion of creative modelling as fantasia" (Danesi 2000: 103). However intriguing, the comparison of the two great semioticians in Danesi's article A Note on Vico and Lotman: Semiotics as a "Science of the Imagination" (2000) remains somewhat unsatisfactory for it suggests many parallels, but discusses almost none of them explicitly.

\subsubsection{Poetic modelling activity}

The work of Vico's fantasia, ingegno and memoria can be seen in Lotman's terms as primary modelling activity — an activity that has certain rules of analogy for creating models and that is connected to a certain modelling system (Lotman 1967: 130-131).

According to the definition by the cognitive scientist Robert E. Haskell, the poetic logic produced by fantasia, ingegno and memoria is 'a nonconscious set of primitive 'metaphorical' cognitive 


\section{Tuuli Raudla}

operations which only later become abstracted into what we now understand as logic" (Haskell 2000: 352). The term 'logic' itself presupposes the existence of some operational rules, at the same time taking into account that when Vico speaks of primordial consciousness, it is clear that 'logic' is not understood directly in his notion of poetic logic. In Vico's words, "That which is metaphysics insofar as it contemplates things in all the forms of their being, is logic insofar as it considers things in all the forms by which they may be signified" (Vico 1984: 400). In Vico's view, logic occupies itself with the forms of signification. The rules that direct the process of signification are based on metaphorical identification, not on syllogistic operations. Generally speaking — the elements of the modelling system that are produced by poetic logic are imaginative universals.

Poetic logic is not a means for objective perception of the world, it is a means for creating the world, that is, modelling activity. The notion of modelling can be linked to the verum-factum principle of Vico. Verum-factum signifies the affinity of the truth and meaning creation. This principle is first expressed in an early work of Vico On the Most Ancient Wisdom of the Italians as "verum (the true) and factum (what is made) are interchangeable, or [...] they are convertible" (Vico 1988 [1710]: 45). The true and the made are one and the same. Humans can gain no direct knowledge about the world; as Vico sees it, they have an external relation to the world created by god. Trying to make sense of this world, people produce images of it. These images are those that people have an inner relation with; they are an expression of an accessible truth (Verene 1991: 36-37). By making sense of the world, by giving it signification, people create their world and true knowledge about this world is to be found in the modifications of the human mind.

And they should have begun with metaphysics, which seeks its proof not in the external world but within the modifications of the mind of him who meditates it. For since this world of nations has certainly been made by men, it is within these modifications that its principles should have been sought. (Vico 1984: 374)

Humans are capable of creating a realm that is to a certain limit independent of the physical reality as it forms the mental space of possible worlds. "The species-specific trait of the human being is a modelling device capable of inventing many worlds, differently from 
other animals" (Ponzio 2006: 238). This capability is a derivate of imagination (fantasia) and Vico believed it to be provided by nature - its roots are in the human body. People were "furnished by nature with these senses and imaginations" (Vico 1984: 375). Augusto Ponzio (2006: 238) interprets this statement in terms of evolution and concludes that the humans were furnished with the capability of language when they appeared as a species. Thus the human beings have an Umwelt just like all other life forms do, but they have a peculiar relation to it. Their Umwelt is a ground for exclusively human mental processes that lead to multiplicity of imaginative structures and choices. According to Deely, the essence of the different nature of human Umwelt is 'idea' in a specific semiotic sense - that is:

the relationship itself constituting signification, grasped according to the being it has as distinguishable both from a given signified and from a given signvehicle, and therefore as detachable from any given vehicle and attachable to any other vehicle, and as directable to some other object as well, or to the same object only, in its new attachment. (Deely 1991: 544)

Thus human beings are capable of cognizing sign relations and the arbitrariness of signs. Therefore, "the mind can, with a little cleverness, turn every element of experience and discourse into a plaything ad infinitum" (Deely 1991: 561).

For all organisms, the contact with external reality is mediated and selective as such. The selection is determined biosemiotically, but in case of humans, imagination interferes in this process - as it forms poetic meaning, creating connections between some perceptual images, thus multiplying their importance, and declares some images nonexistent. This process is characterized by the modelling potential of culture:

$[\ldots]$ that is, either the ability to describe as wide a range of objects as possible, which would include as many as yet unknown objects as possible, this being the optimal requirement for cognitive models, or it should have the capability to declare these objects which it cannot be used to describe as nonexistent. (Lotman, Uspenskij 1978a: 222)

The modelling potential of a system depends on how many objects it is able to describe. Poetic logic is flexible and prepared for creating new relations. Imaginative universals, considering their openness to entering into new unpredictable connections, have a bigger modelling 


\section{Tuuli Raudla}

potential than descriptive class concepts. At the basis of cultural modelling, there is the selective inclusion of phenomena in meaning creating processes.

The first and most important act of any semiotic modelling of a culture is to pick out the layer of culturally relevant phenomena in the surrounding world. To do this there has to be some primary encoding. This primary encoding may be realized by identifying real-life situations with mythological ones, and real people with the people of myth or ritual. (Lotman 2001: 58)

Lotman no more than describes the elements and the processes already existent in the mythological mind. Vico tries to find the beginning of them.

\subsubsection{The iconicity of models}

Poetic forms created by fantasia may be seen as models. It is important to repeat here that according to Lotman (1967: 131), only iconic signs may be seen as models - as signs that relate to their object in a way determined by the modelling system they belong to.

Danesi equalizes the Vichian poetic forms with iconic signs units of thought that stand for their referents in a direct way (Danesi 2000: 102). Vico describes Vulgar Latin" as a language "which has formed almost all its words by metaphors drawn from natural objects according to their natural properties or sensible effects" (Vico 1984: 444). As mentioned above, models follow certain rules of analogy as they stand for an object in a system. In the case of primary modelling, it may be presumed that these rules were based on iconic representation.

In the article Myth - Name - Culture, Lotman and Uspenskij claim that "although iconic signs are to some extent closer to mythological texts, they are, just like conventional signs, a phenomenon of a principally different type of consciousness" (Lotman, Uspenskij 1973: $294)^{2}$. This argument is probably based on the narrower definition of the icon as similarity (see Lotman 2001: 54). As Lotman and

\footnotetext{
The terms 'vulgar' and 'nations' are used in The New Science in the sense of culturally primordial.

2 I refer here to the Russian original of the article, since the passage has been omitted from the English translation (Lotman, Uspenskij 1978b).
} 
Uspenskij (1978b: 219) exclude metaphor from the mythological text, there cannot be any icons either. As shown above, in the Vichian tradition, the metaphor is not based on similarity. The icon is understood as a perceptual relation of whatever kind between the sign and the object. In spite of the differences in terminology, both Vico on one hand and Lotman with Uspenskij on the other, suggest that the archaic mind did not operate by means of similarity relations.

Although the iconic signs used in modern culture are more or less arbitrary and based on similarity, it is theoretically still possible to construct the primal iconic signs - images based on sensory identity that were part of the early poetic consciousness.

Vico says about the primal mute signs that they were "in their own right the best emblems, for they carried their meaning in themselves" (Vico 1984: 484). The origin of those signs was, in Vico's view, the human body: meanings were fixed by natural relations; that is by identity relations based on perceptual information (Vico 1984: 444). The senses are the sole way of knowing something (Vico 1984: 374). Danesi divides the iconic processes taking place in the poetic logic into two. Internal iconicity "presents an imagistically modelled referent to perceptual memory for appropriate storage" (Danesi 1993: 69). External iconicity represents "the imagistically modeled referent outside the mind through some form of visual mimesis" (Danesi 1993: 69). The concept is somewhat simplified for it seems to presuppose that the iconic units are visual and not related to any other sensory channels.

Lotman does not describe the relation between iconic signs and perception, but he mentions the possibility that the binary organization of an intellectual unit could be the result of the need to integrate perceptual information from different sensory organs.

While transforming the external irritations in a similar way, paired sense organs are spaced apart and "see" the world from different angles. This renders the constructed image stereoscopic. The next step in structuralisation is the formation of structurally contrasted pairs: unifying two visual aspects of an object is easier than the integration of visual and auditory images of the world. But exactly for the reason that these images are rationally untranslatable into each other and an effort is required for their integration, they represent an important phase in the genesis of the asymmetry of the brain hemispheres. The structure of other meaning generating systems is analogical. (Lotman 1981a: 10) 


\section{Tuuli Raudla}

Vico and Lotman have quite a different starting point: Vico is interested in the formation of the image and trope based on sensory information, Lotman suggests that the activity of sensory organs is the basis for the appearance of translation mechanism. But both turn to body and senses in order to explain essential intellectual phenomena.

The peculiarity of the model is that because of its iconic nature it is able to stand for an object in a useful way in the process of structuring the world. Iconic modelling brings to the world of signs partially the structure of the perceptible object - the structure of the sign is in accordance with the structure of the object. This is the key to the usefulness of the icons - they are as if objects, and at the same time they are free from any physical restraints.

\subsubsection{Bilingualism}

In Lotman's conception, the binary organization of a unit is a precondition for any semiotic creativity in it. In Lotman's view, all intellectual units have an invariant structure.

An invariant for all these will be a bipolar structure, with a generator of discrete texts located on one pole and a non-discrete texts on the other. In the output of the system, these texts interfuse, forming a unified, multi-layered text where the mutually untranslatable codes intertwine in a multitude of ways. When gating a text through such a system, we get an avalanche-like self-reproduction of meanings. If a block of new messages is integrated into the system, that are declared "appropriate" in accordance with certain rules, and a memory mechanism for saving these messages, we get the structural invariant. (Lotman 1981a: 10-11)

Although the translation between the discrete and the continuous texts is the main mechanism of meaning generation, it is not the only one. "The opposition 'discrete-continuous' is merely one possible form, an extreme one, of producing tropes of semantic untranslatability" (Lotman 2001: 38). The precondition for the activity of an intellectual unit is, as mentioned above, the integration of two or more structures that model the external reality differently (Lotman 1981a: 10). In the archaic mind, the verbal-discrete thought was not fully developed. In Danesi's view, the primordial signs are iconical continuous images (Danesi 1993: 84) that are connected by the mechanism of metaphorical identity. As the images are linked together and so are in 
turn the images formed in this way, the structure becomes more and more complicated, until it calls for an organization of a different kind.

As it [metaphor - T. R.] proceeded to generate more abstract concepts by connecting those of the second order, the rational mind, with its syntactic abilities, emerged to stabilize the increasingly complex surface-level system. (Danesi 1993: 121)

As Danesi sees it, syntactic organization could not have been the discrete language in the meaning creating translation processes in the archaic consciousness. Apparently, Danesi understands syntax as a linguistic-verbal entity.

Ponzio, on the other hand, does not tie syntax to verbal language; he claims that the syntactics of language is the capacity that allows for the combination of a finite number of elements in infinite number of ways, so that a new meaning arises in each combination (Ponzio 2006: 241). He uses the term syntactics on purpose, rather than the term syntax, in order to avoid associations with the linguistic-verbal meanings of the latter. For Ponzio, the syntactics of language can be described as writing - a procedure of combination that precedes verbal language and is a precondition for it (Ponzio 2006: 241).

To signify with the same elements through different positions is already writing, and articulation of verbal language and through verbal language [...] takes place on the basis of this type of signification through position. (Ponzio 2006: 241)

The existence of discrete units and the possibility to position the same unit differently is the precondition for free combination. In Vico's system, fantasia creates the images that can be separated from the context, and ingegno arranges them into different relations. The primal capability of combining (Ponzio's writing) is the basis for the emergence of linguistic-verbal syntax.

Poetic meaning creation process is based on metaphorical identity. The meaning units arising from this identification can in turn be identified with each other. In order to identify two units so that a new meaning arises, there has to be some dissonance between them - it need not be the opposition of discrete-continuous. The creativity of primal metaphors lies in the fact that they juxtapose two or more independent elements that could not have been connected without 


\section{Tuuli Raudla}

using imagination. In a state where the fixed associations are scarce, almost all acts of identification have to be metaphorical and creative.

In his article On the Semiosphere, Lotman claims that elements of the iconic and verbal language cannot be directly isomorphic, but "each of them, in a variety of ways, is isomorphic in the extrasemiotic world of reality, which they represent in a given language" (Lotman 2005: 216). In Vico's terms, the isomorphism with reality is a product of fantasia and the isomorphism between images is a product of ingegno. The relations established by ingegno would be meaningless if they were not based on perceptual images.

Danesi also interprets Vico's theory of primordial images in terms of the cognitive functions of hemispheres. The left hemisphere is responsible for rational analytical thought, the right hemisphere for spatial memory, intuition and the capability of synthesis (Danesi 1993: 97). Danesi presents the results of neuropsychological studies that support the hypothesis of the iconic nature of the archaic consciousness: the brain centres occupied with perception and mental images are the same; right hemisphere functions are iconic in their nature; right hemisphere is active in understanding and saving new information; right hemispheric capability to produce images is phylogenetically prior to left hemispheric capability of abstract conceptualization; the flow of information goes "from right to left" in case of acquiring new information - from image-based to abstract (Danesi 1993: 98).

If archaic thought was iconic, then it had to be the right hemisphere that controlled the main primordial mind processes and only later the role of the left hemisphere increased as the power of abstraction grew (Danesi 1993: 85). Still, both hemispheres had to be involved from the beginning: complex thought only arises when both hemispheres work in tandem (Danesi 1993: 97). In the process of metaphor both hemispheres are involved:

In the case of MLP [metaphorical language programming $-T$. R.], the RH [right hemisphere $-T$. R.] can be said to control the iconic context-structure of metaphor and the LH [left hemisphere $-T$. R.] its form-structure and ultimate conceptualization. (Danesi 1993: 138)

Lotman (2001: 54-62) emphasizes the meaning creating potential of iconic representation. The primacy of iconic signs in Lotman's concept is proposed in the claim that iconic signs are close to mytho- 
logical texts (Lotman, Uspenskij 1973: 294). Iconicity is considered to be the dominating organizing principle in the mythological consciousness: "a living myth is iconic-spatial and is realised as a sign in activities and the panchronic being of drawings, in which, for instance, in cave- and petroglyphic drawings, there is no linearly fixed order" (Lotman, Uspenskij 1978b: 7). At the same time, in the mythological consciousness as in any other type of consciousness, there has to be a discrete language to oppose the continuous one. The dialogue between the two hemispheres, one of which creates continuous organization and the other discrete organization, is in the focus of Lotman's understanding of meaning creation (Lotman 1981b: 9-10; 1978: 8).

Lotman derives the invariant structure of a meaning creating unit from the comparison of the dual organization of the human brain and the principles of functioning of the structure of text and culture.

The left and right hemisphere of the human brain, different language subtexts of a text and the principal polyglotism of culture (bilingualism being a minimum model) form a single invariant model: any intellectual unit consists of two (or more) integrated structures. (Lotman 1981a: 10)

Danesi ends up interpreting Vico through the functioning principles of the hemispheres, on the ground of Vico's assertion that image based thinking is primordial. Generally, linguists have in most part been interested in the functions of the left hemisphere, but following the Vichian line of thought, it is inevitable that the workings of both hemispheres have to be considered. This type of approach leads to understanding the consciousness as a dialogical phenomenon. As Lotman remarks on the co-existence of verbal-discrete and iconic languages:

Although on different stages of human history one or the other of these universal language systems pretends for globality and may indeed achieve a dominant state, the bipolar construction of culture is not thereby destroyed, but takes more complicated and secondary forms. (Lotman 1978: 6)

Lotman states that translation and dialogue are the preconditions of meaning creating processes. Vico has never explicitly made such a claim, but developments of his theories easily come to the same conclusion. 


\section{Conclusion}

The primordial images and textuality arise in the course of a process of poetic translation. The dominant type of models in the archaic consciousness is icons that are formed on the basis of sensory information. Iconicity dominates also in the organization of the models themselves. At the same time, these iconic and iconically organized images can be positioned and combined in an infinite number of ways - this feature, the primal syntactics or writing as Ponzio puts it, plays the role of discrete organization in the meaning generating translation process. The primal syntactics does not follow the rules of descriptive logic as it generates texts. The distinctive characteristic of archaic consciousness is using the mechanism of identity rather than that of similarity, and dividing the object into parts rather than into features.

The identity-based poetic logic is at the basis of primary modelling, the linguistic-verbal modelling being secondary to it. It may be claimed that at some point, linguistic-verbal texts need to be translated into the language of images, that is, into the language of some poetic modelling system. The language of images does not only form one counterpart in a bilingual (continuous-discrete) meaning generating unit - although at a higher level it functions as such - it is also capable of acting as an independent heterogeneous meaning generating system.

The Vichian-Lotmanian approach does not only give us the elements and rules of the poetic modelling system, it also presupposes its bodily origin. It inevitably includes body as a primary source of meaning creation in the description of consciousness and thus brings forth the derivative nature of the dualistic mind-body conception. ${ }^{3}$

3 Acknowledgement. The author wishes to acknowledge the help of Tanel Pern in translating the citations with quotes from Russian. The work has been accomplished in the Centre of Excellence in Cultural Theory. 


\section{References}

Chang, Han-liang 2003. Is language a primary modelling system? On Juri Lotman's concept of semiosphere. Sign Systems Studies 31(1): 2-23.

Danesi, Marcel 1991. Giambattista Vico and semiotics. In: Sebeok, T. A.; UmikerSebeok, J. (eds.), The Semiotic Web 1990. Berlin: Mouton de Gruyter, 89-109.

- 1993. Vico, Metaphor, and the Origin of Language. Bloomington: Indiana University Press.

- (ed.) 1995a. Giambattista Vico and Anglo-American Science: Philosophy and Writing. Berlin, New York: Mouton de Gruyter.

- 1995b. Cognitive science: Towards a Vichian perspective. In: Danesi, Marcel (ed.) 1995a: 63-85.

- 2000. A note on Vico and Lotman. Sign Systems Studies 28: 99-113.

Deely, John 1991. Modelling anthroposemiosis. In: Anderson, Myrdene; Merrell, Floyd (eds.), On Semiotic Modelling. Berlin, New York: Mouton de Gruyter: 525-593.

- 2005. Basics of Semiotics. Semiootika alused. (Tartu Semiotics Library 4.) Tartu: Tartu University Press.

Harkin, Michael 1998. Claude Lévi-Strauss. In: Bouissac, Paul (ed.), Encyclopedia of Semiotics. Oxford: Oxford University Press, 364-366.

Haskell, Robert E. 2000. Cognitive science, Vichian semiotics and the learning paradox of the Meno: Or what is a sign a sign of? In: Perron, Paul; Sbrocchi, Leonard G.; Colilli, Paul; Danesi, Marcel (eds.), Semiotics as a Bridge Between the Humanities and the Sciences. Toronto: Legas Press, 336-370.

Ivanov, Vyacheslav V.; Lotman, Juri M.; Pjatigorski, Aleksandr M.; Toporov, Vladimir M.; Uspenskij, Boris A. 1998. Theses on the Semiotic Study of Cultures (as applied to Slavic texts). Tartu Semiotics Library 1: 33-60.

Lakoff, George; Johnson, Mark 1999. Philosophy in the Flesh: The Embodied Mind and its Challenge to Western Thought. New York: Basic Books.

Lévi-Strauss, Claude 1969. The Savage Mind. Chicago: The University of Chicago Press.

Lotman, Juri 1967. Tezisy k probleme "Iskusstvo v ryadu modeliruyuschih system". Trudy po znakovym sistemam (Sign Systems Studies) 3: 130-145.

- 1978. Fenomen kul'tury. Trudy po znakovym sistemam (Sign Systems Studies) 10: 3-17.

- 1981a. Mozg — tekst — kul'tura — iskusstvennyj intellekt. Semiotika i informatika 17(1): 3-17.

- 1981b. Ritorika. Trudy po znakovym sistemam XII. Uchenye zapiski Tartuskogo gosudarstvennogo universiteta 515: 8-28.

- 1992. Kul'tura i vzryv. Moskva: Gnozis.

- 1995. Rol' iskusstva v dinamike kul'tury. Studia Russica Helsingiensia et Tartuensia IV: 9-24.

- 1997. Culture as a subject and an object in itself. Trames 1(1): 7-16.

- 2001. Universe of the Mind. London: I. B. Tauris Publishers.

— 2005. On the semiosphere. Sign Systems Studies 33(1): 215-239. 


\section{Tuuli Raudla}

Lotman, Juri; Mints, Zara 1981. Literatura i mifologiya. Trudy po znakovym sistemam (Sign Systems Studies) 13: 35-55.

Lotman, Juri; Uspenskij, Boris 1973. Mif — imya — kul'tura. Trudy po znakovym sistemam (Sign Systems Studies) 6: 282-303.

- 1978a. On the semiotic mechanism of culture. New Literary History 9(2): 211-232.

- 1978b. Myth - Name — Culture. Semiotica 22(3/4): 211-233.

Nuessel, Frank 1995. Vico and current work in cognitive linguistics. In: Danesi, Marcel (ed.) 1995a: 127-146.

Nöth, Winfried 2006. Yuri Lotman on metaphors and culture as self-referential semiospheres. Semiotica 161(1/4): 249-263.

Ponzio, Augusto 2006. Metaphor and poetic logic in Vico. Semiotica 161(1/4): 231-248.

Sebeok, Thomas Albert 1988. In what sense is language a "primary modelling system"? In: Broms, Henry (ed.), Semiotics of Culture. Proceedings of the $25^{\text {th }}$ Symposium of the Tartu-Moscow School of Semiotics, Imatra, Finland, $27^{\text {th }}$ $29^{\text {th }}$ July, 1987. Helsinki: Arator INC. Publishers, 67-80.

- 2001. Some reflections on Vico in semiotics. In: Sebeok, Thomas A., Global Semiotics. Bloomington: Indiana University Press, 135-144.

Sebeok, Thomas A.; Danesi, Marcel 2000. The Forms of Meaning: Modeling Systems Theory and Semiotic Analysis. Approaches to Applied Semiotics 1. Berlin, New York: Mouton de Gruyter.

Verene, Donald Phillip 1991. Vico's science of imagination. Ithaca: Cornell University Press.

- 1995. Imaginative universals. In: Danesi, Marcel (ed.) 1995a: 201-212.

Vico, Giambattista 1984 [1744]. The New Science. Ithaca: Cornell University Press.

- 1988 [1710]. On the most ancient wisdom of the Italians: Unearthed from the origins of the Latin language. Ithaca: Cornell University Press.

\section{Вико и Лотман: поэтическое смыслообразование и первичное моделирование}

В статье рассматриваются идеи Юрия Лотмана и Джамбаттиста Вико о смыслообразовании и архаичном мышлении. Сравниваются, с одной стороны, такие понятия Вико, как fantasia, ingegno, memoria и поэтическая логика, и с другой - концепция Лотмана о тексте, памяти и моделирующей системе. При рассмотрении идей Вико автор статьи основывается во многом на работах Дональда Филипа Верена и Марселя Данези. Цель статьи - показать характерные черты архаического смыслообразования.

Архаическое мышление по существу является поэтическим. Главным механизмом его смыслообразования является метафорическое 
отождествление двух отдельно стоящих элементов. Такая деятельность генерирует новые смыслы значения - элементы, отождествляемые с помощью воображения, не могут отождествляться средствами логики силлогизмов. Архаическое мышление не оперирует абстрактными понятиями, как рациональное мышление а создает имагинативные универсалии. Имагинативные универсалии основываются не на подобии/различии свойств объекта, а на тождестве объектов или их частей. Процесс отождествления является основой поэтического моделирования, что первично по отношению к вербальному моделированию.

\section{Vico ja Lotman: Poetiline tähendusloome ja primaarne modelleerimine}

Artikkel põhineb Juri Lotmani ja Giambattista Vico arusaamadel tähendusloomest ja arhailisest mõtlemisest. Võrdluse alla tulevad ühelt poolt Vico mõisted fantasia, ingegno, memoria ja poeetiline loogika ning teiselt poolt Lotmani teksti, mälu ja modelleeriva süsteemi kontseptsioon. Vico käsitlemisel arvestatakse olulisel määral Donald Phillip Verene'i ja Marcel Danesi käsitlusi tema töödest. Artikli eesmärgiks on tuua välja arhailise tähendusloome iseloomulikud jooned.

Arhailine mõtlemine on põhiolemuselt poeetiline. Selle põhiliseks tähendusloomemehhanismiks on kahe eraldiseisva elemendi metafooriline samastamine. Taoline tegevus on uut tähendust loov - elemendid, mis samastatakse kujutlusvõimet kasutades, ei ole süllogistilise loogika abil samastatavad. Arhailine mõtlemine ei opereeri üldmõistetega nagu ratsionaalne mõtlemine, vaid loob hoopis kujutluslikke universaale. Kujutluslikud universaalid ei põhine mitte objektide omaduste sarnasusel/ erinevusel, vaid objektide või nende osade omavahelisel samasusel. Samastamisprotsess on aluseks poeetilisele - verbaalse modelleerimise suhtes esmasele — modelleerimisele. 
